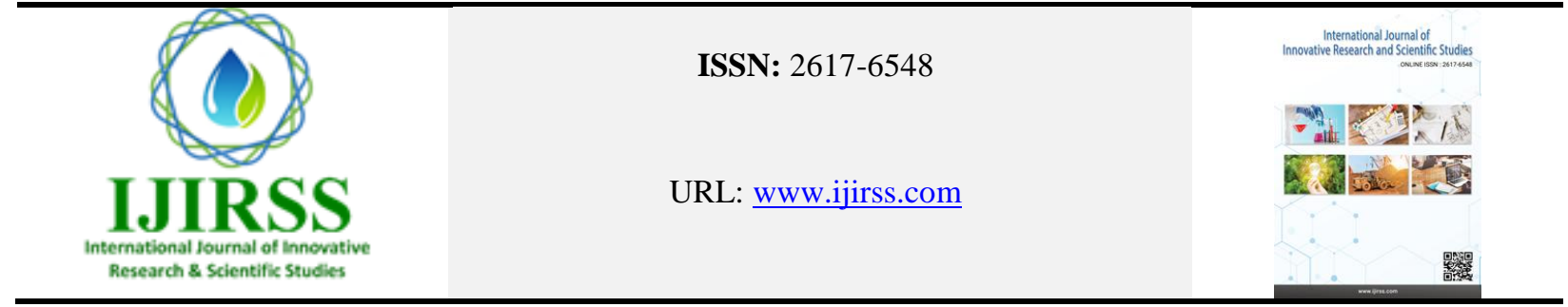

\title{
Correlation Coefficient between Some Productive and Reproductive Traits of Jersey and Red Sindhi Crosses
}

\author{
Zekrullah Motmain $^{1 *}$, Ram Pal Singh ${ }^{2}$ \\ ${ }^{1}$ Faculty of Agriculture, Parwan University, Parwan, Afghanistan \\ ${ }^{2}$ Faculty of Animal Husbandry, Sam higginbottom institute of agriculture, technology and sciences (SHIATs) deemed-to-be-university, \\ Allahabad Utter Pradesh (U.P.), India \\ *Corresponding author: Zekrullah Motmain (zekrullah.z@yahoo.com)
}

\begin{abstract}
The observation on relationship between some productive and reproductive traits of Jersey (J) x Red Sindhi (RS) cows. The data for the study were collected from 50 history sheets records maintained in the department of animal husbandry, Sam Higginbottom Institute-Deemed-to-be-Allahabad University, dairy farm Allahabad for the period from 1944 to 1960 Animals were managed by skilled persons under similar management condition. The mean of first second and third lactation length, lactation yield were 370.200 days, 474.320 days, 368.320 days, $1887.273 \mathrm{~kg}, 1975.961 \mathrm{~kg}$, and 1731.426 $\mathrm{kg}$ respectively. The mean of age at calving, first and second calving interval were 983.86 days, 436.44 days and 454.68 days respectively. There was high degree correlation between productive and reproductive traits. A total of 18 correlation coefficients were collected for determining the correlation between lactation length, lactation yield and age at calving, first and second calving interval. From 18 correlation, 10 values were found significant and 8 values were found non-significant.
\end{abstract}

Keywords: Body parameters, Productive traits, Reproductive traits, Correlation.

DOI: $10.53894 /$ ijirss.v2i1.14

Funding: This study received no specific financial support.

History: Received: 14 January 2019/Revised: 12 February 2019/Accepted: 21 March 2019/Published: 29 March 2019

Licensed: This work is licensed under a Creative Commons Attribution 4.0 License $(\mathrm{cc}) \mathrm{Er}$

Acknowledgement: Both authors contributed to the conception and design of the study.

Competing Interests: The authors declare that they have no conflict of interests.

Transparency: The authors confirm that the manuscript is an honest, accurate, and transparent account of the study was reported; that no vital features of the study have been omitted; and that any discrepancies from the study as planned have been explained.

Ethical: This study follows all ethical practices during writing.

\section{Introduction}

Livestock rearing is one of the most important economic activates in the rural areas of the India providing supplementary income for most of the families dependent on agriculture. Apart from providing a subsidiary income to the families, rearing of livestock such as cattle, buffaloes, sheep, goats, and poultry a source of nutrition in the form of milk, eggs and meat. Owing to conducive climate and topography, Animal Husbandry Sector have played prominent socioeconomic role in India. Livestock in agriculture particularly the cattle and buffaloes have important contribution in different agricultural operations, to maintain soil fertility and to provide cash for purchase of various inputs used in crop production, the sale of various livestock products like milk and milk products, meat, egg and wool is a good source of income for livestock owner. The cash received is used for purchase of various inputs like quality seeds, fertilizers, 
pesticides and agriculture implements. It has been found that in the time of exigencies like drought and other natural calamities, it is the livestock, which comes to the rescue of the vast sections of rural population. As the ownership of livestock is more evenly distributed with landless labourers, small and marginal farmers, the progress in this sector will result in a more balanced development of the rural economy [1, 2]. Crop husbandry and animal husbandry are dependent on each other in India, mainly because of small holding of land by majority of the farmers. Unlike the agriculture in western countries, India agriculture depends almost entirely on cattle to meet its draught requirement. Bullocks and buffaloes are the main draught animals employed in different agricultural operations. Females of these bovines are the main source of milk and complete protein of animal origin. The male calves born are mostly used for traction purposes. Total Livestock population in world are 1372 million and total livestock population in India were 529.7 million in (2012), livestock population in India (2007) cow 19.91 crore buffalo 10.53, sheep 7.16, goat 14.05 crore, camel 5,17 lakh [3].

Animal improvement program is needed to increase milk production, selection is the keystone for any such animal improvement program. Selection may be of several kinds; depending upon the sources of information used to evaluate the animals. Milk production performance is one of the major economic traits in the dairy cattle program. Therefore, it becomes more relevant to tackle out the means for ameliorating the performance efficiencies by developing certain guidelines for selection. Indeed, the knowledge of genetic variability with respect each trait and co-variability existing among different traits are a beacon light for planning appropriate selection and breeding strategies for the genetic improvement of dairy animals [4]. Milk production and reproduction are major factors affecting on efficiency and profitability of dairy industry. In most countries breeding programs were mainly oriented toward yield traits. Selection for higher yields of dairy cattle has led to decline in fertility due to unfavorable genetic correlation between yield and fertility $[5]$.

\section{Materials and Method}

The data for the study were collected from 50 history sheets records maintained in the Department of Animal Husbandry, Sundaresan School of Animal Husbandry and Dairying, Sam Higginbottom Institute deemed-to-be-University, dairy farm Allahabad for the period from 1944 to 1960 animals were managed by skilled persons under similar management condition. The following economic traits are under study.

\subsection{Productive traits} study:

Indicate the production of the animals these are different in different species the following productive traits are under

1. First, second and third lactation milk yield

2. First, second and third lactation length

\subsection{Reproductive traits:}

1. Age at first calving

2. First and second calving interval

\subsection{Statistical Analysis:}

\subsubsection{Phenotypic correlation}

Correlation is a statistical technique that can show whether and how strongly pairs of variables are related. For Analysis of phenotypic correlation among the two traits X and Y mostly the Karl Pearson's (1896) correlation formula used [6]. The following is Karl Pearson's correlation Equation 1:

$$
\begin{array}{r}
r_{x y}=\frac{c o v_{x y}}{v x . v y} \\
\sqrt{\left\{\sum x^{2}-\frac{\left(\sum x\right)}{N}\right\}\left\{\sum x^{2}-\frac{\left(\sum x\right)}{N}\right\}}
\end{array}
$$

where $r_{x y}=$ correlation coefficient between characters $\mathrm{x}$ and $\mathrm{y}$

$c o v_{x y}=$ co-variation between characters $\mathrm{x}$ and $\mathrm{y}$

$v x=$ Variance for $\mathrm{x}$ character

$v y=$ Variance for $\mathrm{y}$ character

\section{Results and Discussion}

\subsection{Correlations of lactation length and age at calving}

The Internet users. The correlation between first, second and third lactation length with age at calving of Jersey $\mathrm{x}$ Red 
Sindhi cow presented in Table 1. The following observations were made. The correlation between first lactation length with age at calving indicated positive $(0.191541)$ non-significant correlation and the second lactation length with age at calving was found negative correlation (-0.05296) significant. Ahmad, et al. [7] similar result reported the lactation length with age at calving has negative correlation (-0.05). Third lactation length with age calving showed positive (0.161511) nonsignificant correlation.

\subsection{Correlations of lactation length with age at first and second calving interval}

The correlation between lactation length with age at first calving and second calving interval: of Jersey x Red Sindhi presented in Table 2. The following observations were made. The correlation of first lactation length with age at first calving was found positive (0.378283) non-significant correlation, similar result reported by Ahmad, et al. [7] reported the lactation length with age at first calving has positive (0.25) non-significant correlation, first lactation length and with age at second calving showed negative (-0.22496) significant correlation. The second lactation length with age at first calving was found negative $(-0.12387)$ significant correlation, second lactation length with age at second calving indicated positive (0.035658) non-significant correlation, third lactation length with first calving was found negative (-0.02927) significant correlation, third lactation length with age at second calving indicated positive (0.330812) non-significant correlation. Wilson, et al. [8] reported a correlation of only 0.08 between lactation length and calving interval in Kenana cattle. Mukasa-Mugerwa [9] found age at first calving to be positively correlated with lactation milk yield and lactation length in Gangatiri cattle.

\subsection{Correlation of lactation yield and age at calving}

The correlation between first, second and third lactation yield with age at calving of Jersey x Red Sindhi presented in Table 3. The following observations were made. The correlation between first lactation yield with age at calving was found negative (-0.0958) significant correlation and the second lactation yield with age at calving was showed negative correlation (-0.08268) significant. The third lactation length with age calving was found negative (-0.01873) significant correlation. Tabbaa and AI-Atiyyat [10] similar result reported the correlation between the year of calving and average daily milk yield were negative correlation ranged from -0.18 to -0.14 . Elemam and Nekheila [11] similar result reported that age at first calving had non-significant effect on total milk yield.

Table-1.

Correlation of first, second and third lactation length with age at first calving.

\begin{tabular}{l|l|l|l|l}
\hline No. & $\begin{array}{l}\text { Parameters correlated } \\
\text { (days) }\end{array}$ & $\begin{array}{l}\text { Correlation } \\
\text { Coefficient }\end{array}$ & $\begin{array}{l}\text { Table } \\
\text { value }\end{array}$ & F-test \\
\hline 1 & First lactation length and age at first calving & 0.191541 & 1.352 & NS \\
\hline 2 & Second lactation length and age at first calving & -0.05296 & -0.367 & S \\
\hline 3 & Third lactation length and age at first calving & 0.161511 & 1.134 & NS \\
\hline
\end{tabular}

Table-2.

Correlation of first, second and third lactation length with first and second calving interval.

\begin{tabular}{l|l|l|l|l}
\hline No. & $\begin{array}{l}\text { Parameters correlated } \\
\text { (Days) }\end{array}$ & $\begin{array}{l}\text { Correlation } \\
\text { coefficient }\end{array}$ & Table value & F-test \\
\hline 1 & First lactation length and first calving interval & 0.378283 & 2.831 & $\mathrm{NS}$ \\
\hline 2 & First lactation length and second calving interval & -0.22496 & -1.600 & $\mathrm{~S}$ \\
\hline 3 & Second lactation length and first calving interval & -0.12387 & -0.865 & $\mathrm{~S}$ \\
\hline 4 & Second lactation length and second calving interval & 0.035658 & 0.247 & $\mathrm{NS}$ \\
\hline 5 & Third lactation length and first calving interval & -0.02927 & -0.203 & $\mathrm{~S}$ \\
\hline 6 & Third lactation length and second calving interval & 0.330812 & 2.429 & $\mathrm{NS}$ \\
\hline
\end{tabular}

Table-3.

Correlation of first, second and third lactation yield with age at first calving.

\begin{tabular}{l|l|l|l|l}
\hline \multirow{2}{*}{ No. } & Parameters correlated & Correlation & Table & F- \\
value & test \\
\cline { 3 - 5 } & & coefficient & & 0.233193 \\
1 & First lactation yield $(\mathrm{kg})$ and first calving interval (Days) & 1.661 & $\mathrm{NS}$ \\
\hline 2 & First lactation yield $(\mathrm{kg})$ and second calving interval (Days) & -0.2256 & -1.604 & $\mathrm{~S}$ \\
\hline 3 & Second lactation yield $(\mathrm{kg})$ and first calving interval (Days) & -0.27793 & -2.005 & $\mathrm{~S}$ \\
\hline 4 & Second lactation yield $(\mathrm{kg})$ and second calving interval (Days) & 0.261531 & 1.877 & $\mathrm{NS}$ \\
\hline 5 & Third lactation yield $(\mathrm{kg})$ and first calving interval (Days) & -0.08164 & -0.568 & $\mathrm{~S}$ \\
\hline 6 & Third lactation yield $(\mathrm{kg})$ and second calving interval (Days) & 0.278186 & 2.007 & $\mathrm{NS}$ \\
\hline
\end{tabular}


Table-4.

Correlation of first, second and third lactation yield with first and second calving interval.

\begin{tabular}{l|l|l|l|l}
\hline No. & Parameters correlated & $\begin{array}{l}\text { Correlation } \\
\text { coefficient }\end{array}$ & $\begin{array}{l}\text { Table } \\
\text { value }\end{array}$ & F-test \\
\hline 1 & First lactation yield $(\mathrm{kg})$ and age at first calving (days) & -0.0958 & -0.667 & $\mathrm{~S}$ \\
\hline 2 & Second lactation yield $(\mathrm{kg})$ and age at first calving (days) & -0.08268 & -0.575 & $\mathrm{~S}$ \\
\hline 3 & Third lactation yield $(\mathrm{kg})$ and age at first calving (days) & -0.01873 & -0.130 & $\mathrm{~S}$ \\
\hline
\end{tabular}

\subsection{Correlation of lactation yield and age at first calving and second calving interval}

The correlation between lactation yield with age at first calving and second calving interval of Jersey $x$ Red Sindhi presented in Table 4. The following observations were made. The correlation of first lactation yield with age at first calving was found positive (0.233193) non-significant correlation. Bujko, et al. [5] similar result reported the Correlation between evaluated traits of milk production and age at first calving were lower negative and statistically high significant $(\mathrm{P}<0.0001)$. Ali, et al. [12] reported the correlation between age at first calving and first lactation 305-day milk yield were (0.018). first lactation yield with age at second calving was found negative $(-0.2256)$ significant correlation.

Dabdoub [13] similar correlation reported the correlation between milk production and age at first calving was negative correlation and significant. second lactation length with age at first calving indicated negative (-0.27793) significant correlation, second lactation yield with age at second calving was found positive (0.261531) non-significant correlation, third lactation length with first calving was found negative (-0.08164) significant correlation, third lactation yield with age at second calving indicated positive (0.278186) non-significant correlation. Miller, et al. [14] similar correlation reported the phenotypic correlation of average calving interval calving interval and milk in first lactation ranged from 0.19 to 0.21 . Elemam and Nekheila [11] reported the age at first calving had non-significant effect on total milk yield. Zuzana [15] found positive significant correlation $(0.56775, \mathrm{P}<0.0001)$ between milk production and calving interval. Mukasa-Mugerwa [9], found age at first calving to be positively correlated with lactation milk yield and lactation length in Gangatiri cattle.

\section{Conclusions}

The aim of this study was to observe relationship between some productive and reproductive traits of Jersey $\mathrm{x}$ Red Sindhi cows. The data for the study were collected from 50 history sheets records maintained in the department of animal husbandry, Sam Higginbottom Institute-Deemed to be Allahabad University, dairy farm Allahabad for the period from 1944 to 1960, animals were managed by skilled persons under similar management condition. The mean of first second and third lactation length, and lactation yield were 370.20 day, 474.32 day, 368.32 day, $1887.27 \mathrm{~kg}, 1975.96 \mathrm{~kg}$ and $1731.42 \mathrm{~kg}$ respectively. Age at calving, first calving and second were 983.86 days, 436.44 days and 454.68 days respectively. A total of 18 correlation were collected for determining the correlation between lactation lengths, lactation yield, from 18 correlation 10 value were found significant and 8 were found non-significant, there were high degree correlation between lactation length, lactation yield and calving interval. These parameters may be used by farmers/ breeders for earlier selection of Jersey $x$ Red Sindhi crosses, this will be reducing the expenses by early selection and culling poor producing.

\section{References}

[1] S. S. Tomar, Text book of animal breeding, livestock contribution vol. 76. New Delhi, India: Kalyani Publishers, 2004.

[2] R. Wakchaure, S. Ganguly, P. A. Para, P. K. Praveen, A. Kumar, and S. Sharma, "Development of crossbred cattle in India: A review," International Journal of Emerging Technology and Advanced Engineering, vol. 5, pp. 75-77, 2015.

[3] B. Bayram, O. Güler, M. Yanar, and Ö. Akbulut, "Relationships among body weight, body measurements and estimated feed efficiency characteristics in Holstein Friesian cows," Journal of Tekirdag Agricultural Faculty vol. 3 pp. 64-67, 2006.

[4] S. Dhaka, S. Chaudhary, B. Pander, A. Yadav, and S. Singh, "Genetic studies on production efficiency traits in Hariana cattle," Asian-Australasian Journal of Animal Sciences, vol. 15, pp. 466-469, 2002. Available at: https://doi.org/10.5713/ajas.2002.466.

[5] J. Bujko, J. Candrák, P. Strapák, J. Žitný, and C. Hrnčár, "Evaluation of relationship between traits of milk production and reproduction traits in dairy cows of the Slovak spotted breed," Scientific Papers Animal Science and Biotechnologies, vol. 45, pp. 115-120, 2012.

[6] V. Krishnan, On Pearson spearman and Kendall correlation coefficients: The University of Queensland, Institute for Molecular Bioscience, 2012.

[7] M. Ahmad, J. H. J. van der Werf, and K. Javed, "Genetic and phenotypic correlation for some economic traits in dairy cattle," Pakistan Veterinary Journal, vol. 21 pp. 81-86, 2001.

[8] R. Wilson, P. Ward, A. Saeed, and D. Light, "Milk production characteristics of the Kenana breed of Bos indicus cattle in Sudan," Journal of Dairy Science, vol. 70, pp. 2673-2679, 1987. Available at: https://doi.org/10.3168/jds.s00220302(87)80338-7.

[9] E. Mukasa-Mugerwa, "A review of a reproductive performance of female Bos Indicus (zebu) cattle," 1989.

[10] M. J. Tabbaa and R. M. AI-Atiyyat, "Correlations among some characteristics of lactation curve of Friesian cows raised under the conditions of the Jordan valley," Dirasat, Agricultural Sciences, vol. 30, pp. 143-147, 2003.

[11] M. Elemam and A. Nekheila, "Some productive traits of crossbred dairy cows in the farm of University of Khartoum, Sudan," Emirates Journal of Food and Agriculture, vol. 24, pp. 155-158, 2012.

[12] L. Ali, R. Gill, K. Gondal, Z. Ahmad, M. Anwar, and M. Tahir, "Effect of age at first calving on first lactation performance of Sahiwal cows," Pakistan Journal of Agricultural Sciences, vol. 29, pp. 223-226, 1992. 
[13] S. A. M. Dabdoub, "Milk production and reproductive efficiency in Friesian and Friesian X Sharabi Cows," Al-Anbar Journal of Veterinary Sciences, vol. 2, pp. 48-54, 2009.

[14] P. Miller, L. D. Van Vleck, and C. Henderson, "Relationships among herd life, milk production, and calving interval," Journal of Dairy Science, vol. 50, pp. 1283-1287, 1967. Available at: https://doi.org/10.3168/jds.s0022-0302(67)87613-6.

[15] Z. Riecka and J. Candrák, "Analysis of relationship between production and reproduction traits of Holstein cattle population in the Slovak Republic," Scientific Papers Animal Science and Biotechnologies, vol. 44, pp. 332-336, 2011. 